\title{
The Contributions of Community Radios in Fostering Social Services in Tanzania: An Evaluation of "Maendeleo vijijini" Program by Radio SAUT FM in Misungwi District
}

\author{
Mwidima Peter Charles ${ }^{1}$, Fortunatus Manenosabini \\ ${ }^{1}$ Department of Journalism and Mass Communications, St Augustine University of Tanzania, Mwanza, Tanzania \\ ${ }^{2}$ Department of Journalism and Mass Communication (Radio SAUT FM), St Augustine University of Tanzania, Mwanza, Tanzania
}

Email address:

mwidimapeter@yahoo.com (M. P. Charles)

\section{To cite this article:}

Mwidima Peter Charles, Fortunatus Manenosabini. The Contributions of Community Radios in Fostering Social Services in Tanzania: An Evaluation of "Maendeleo vijijini" Program by Radio SAUT FM in Misungwi District. Social Sciences. Vol. 8, No. 5, 2019 , pp. $255-260$. doi: $10.11648 /$ j.ss.20190805.16

Received: August 15, 2019; Accepted: September 16, 2019; Published: September 26, 2019

\begin{abstract}
Being one among the peripheral countries in the world, the provision and access of social services in the rural areas in Tanzania is still one of the major stumbling blocks facing the country. Access to clean water and health services in the rural Tanzania areas are one of the major challenges facing residents in those areas. Likewise, about $85 \%$ of the roads in the rural Tanzania areas are either rough roads or mad roads. In Misungwi, access to clean drinking water and the provision of health services are still problematic. The roads are also very poor to allow a free movement of people and goods. The focus of this study was to evaluate the contributions made by community radio stations in fostering the improvements of social services in Tanzania. Specifically, the study evaluated the maendeleo vijijini program aired by radio SAUT FM and its contributions in the improvement of roads, safe drinking water, and health services in Misungwi rural area. This was a qualitative research whereby the data collection method used was interviews. A purposive sampling technique was used to select respondents for this study whereby a total of 33 respondents were interviewed. They included; three (3) head of units from Misungwi district, 20 members of the development committee, and 10 local leaders. The finding show that community radios through maendeleo vijijini program had played significant contribution towards the promotion and improvements of social services in the rural areas of Misungwi district. Nearly over $60 \%$ of the interviewees confirmed that the program had played grate contributions in promoting and education residences and government officials about the importance of good roads, safe drinking water, and improved health services. In conclusion, these findings have confirmed that community radios have not played any noticeable contributions in Tanzania. The findings also suggest that running a community radio in Tanzania need to be well prepared in terms of financial and human capital. Because of untrained staff to run the program and financial shortages, community radios will continue suffering because of poor coverage, frequent power cut-offs, poor program preparations, just a few to mention.
\end{abstract}

Keywords: Contributions, Community Radios, Fostering, Social Services, An Evaluation, Maendeleo Vijijini Program, Misungwi District

\section{Introduction}

\subsection{Community Radio Stations}

Community radio stations are a type of radio service that offers a model of radio broadcasting beyond commercial and public service. They usually serve geographic communities around the station and communities' interest and relevant to a local Community because are operated, owned and driven by the communities they serve and support [21]. Likewise, Community radios are not for making profits but for providing a mechanism for facilitating individuals, groups, and communities to tell their own diverse stories, to share experiences and to become active creators and contributors of media contents. According to [17], community radio is a participatory and democratic medium of communication capable of initiating dialogue and stimulating critical thinking at the grass root. This is the medium of 
communication of people in a particular community to speak their own matters in relation to the rest of the world. [1], acknowledged that community radio increase awareness among its audience. This helps the community members to participate actively in their social economic and cultural development to improve their living standards and find solution to their local problems. Community radios facilitate several capacity building activities within a community through exchanging information, networking of groups, provision of skills and training as the key elements of developing a community [4].

\subsection{Characteristics and Significances of Community Radio Stations}

The foremost characteristic of any community radio station is that it is run and operated under nonprofit environment. The reason behind this is that a community radio is established to serve the interest of the communities and thus most of the manpower is very low [14]. Though they are nonprofit making radios, they are neither restricted from rising funds from other means sources of funds. Moreover, a community radio station is that which is normally operates in very specialized areas or communities to serve a specific purpose in the respective communities. It is noted that [17] that a community radio stations per se generally have a large staff of volunteers who work in those community radios on a volunteering basis. In that case, such volunteers may maintain the station, build the station, produce and host programs, or manage the station. However, having paid staff members does not usually conflict with being run by volunteers [14]. Additionally, most of the staff in the community radios work on a voluntary basis though there are no any restrictions on employing paid and professional journalists to work there. Moreover, community radios are established, operated, and or owned by the community, which they serve [24].

Moreover, [17] states that Community radios have creditable powers in the communities they operate in. They are the central to the success of development and democracy. It is a particularly effective means of communication in communities where most people can neither read nor write, as those people can speak and listen because the means of broadcasting in these community radios is the local language or language which is understood by the respective people in a given community. He adds that community radio stations have a very significant role to play in the developmental aspect in a given community because this enables community members to share all developmental matters amongst themselves, this can also help community members to voice their own experiences and to critically examine issues, processes and policies affecting their lives. Community radios have vibrant influence in the education and mobilizing community members in the developmental initiatives and strategies that may result in a better life for listeners.

Furthermore, it is also pointed out [20] that community radios are so useful amongst community members. They act as voice of the voiceless by allowing community members to participate and use the radio stations to give out their views on issues affecting their communities. For example, they may discuss on how they can manage their natural resources, raw materials, community affairs and many other issues. Moreover, community radios are tools for social justice because they effectively respond to a real need to be informed, which is a fundamental right of all members in such communities. Likewise, it is noted [22] that the establishment and existence of community radio stations have also been very vital in the communities where such radio stations operate because members in those communities have a greater chance to increases the partisan and social power, knowledge, and experience of those who participate. According to [20], community radios have a significance role to play especially in the rural areas. This is because they have power to reach out to people in rural settings, people who may not meet or converge in any other places. This is a very vital role played by the community radios bearing in minds that much of the population of Africa is rural, and this has been pointed out as a challenge for developmental projects. Likewise, communities which have community radio stations have very significant benefits as community radios also have the influence to inform listeners and participants to focus on local issues especially those which affects their communities, they can as well mobilize listeners and participants to fully engage in their community developmental issues [20]. In addition, community radios have a greater chance to empower marginalized groups by giving them skills in political communication, helping them develop support networks, and programming for their basics needs or priorities in the community. Community radios fully engage in civic education [17]. A good example can be seen from the 2013 general election in Kenya where community radios played a major role. During the election period the community radio stations in Kenya informed citizens about their civic rights and responsibilities and provided them with the knowledge and information necessary for them to make an informed and sober decision making during the voting process. Apart from provision of civic education, community radios do also engage in peace building during election periods. Since most of the elections in African countries have been characterized by conflicts and instability, community radios have been fully being engaged in airing out peace messages, and sometimes they do invite and give airtime to any peace building agent on institution as a mechanism to restore peace and tranquility during the entire election process. In Kenya for example, during the 2013 general election, most of the community radios invited religious leaders and NGO representatives as an initiative to preach for a peaceful election in the country.

\subsection{An Overview of the State of Community Radios in Tanzania}

In order to establish the state of community radio stations in Tanzania one has to note that there are two distinct levels of community radios in the country as pointed out by Tanzania Communication Regulatory Authority [15]. In that 
case, Tanzania has over 35 community radios which are categorized into two categories of; (i) community radio commercial and (ii) community radio non-commercial.

\subsubsection{Community Radio Commercial}

The community radio commercial in Tanzania are those radio stations which have some features of community radios but in nature they are commercially oriented. Most of their programs appear not to target the needs of their listeners or communities. Their major concentration is to maximize profit and not to serve the people in their localities, in other words, they are less to people participation like the purely community radios. Most of the community radio commercial in Tanzania are established at district level and thus they serve very few people in the country. Thus, there is a need for the government and or any other stakeholders in the country to invest more in community radios in order to allow majority of community members in other district participate to the developmental goals of the country through the various programs aired by community radios. Currently, Tanzania has about $20(15 \%)$ community radios in operation which are commercially oriented.

\subsubsection{Community Radio Non-commercial}

Apart from the presence of about 20 community radio stations in the country, Tanzania also has about 14 (11\%) community radio stations in operations which appear to purely accommodate characteristics of a community radio per se. The difference between these two categories of community radios is that community radio commercial are those community radios which do engage in some advertisements and other strategies to make profit whereas the latter only focuses at serving the community with less attention on maximizing profit [23]. However, there are other categories of radio stations listed by TCRA as commercial radios $53(41 \%)$, non-commercial radios $40(31 \%)$, and 2 public radio stations $(2 \%)$ and commercial radio stations.

\section{An Overview of the Provision of Social Services in Tanzania}

\subsection{Concept of Social Services}

Social services are a variety of public services provided by the government, private, profit and non-profit organisations $[3,18]$. They aim at creating more effective organisations, build stronger communities and promote equality and opportunity [12]. Social services include the benefits and facilities such as education, food subsidies, health care, police, fire service, job training, subsidised housing, adoption, community management and policy research [19]. Furthermore, social services is a range of public services created using local or regional data, evidence, research and facts provided by the government, public sector, private sector and voluntary sector employees and organisations to ensure individuals, couples, parents, families and communities receive the Social Services [8]. Generally, social services provide a wide range of services which vary from one locality, city or town to another.

\subsection{Provision of Social Services in Tanzania}

Social services in Tanzania from independence time in 1961 have been considered as a wide range of government's responsibility. Policy makers in Tanzania have sought to extend health, education, water and other social services to the largely rural population of the country Wangwe \& Rweyemamu (2001) cited in [5,7]. The aspect of social services in the country can also be traced back after independence (1961) to the early 1980s, especially in the water sector where most households especially in rural areas drained water from natural sources of water [10]. The government then continued to increase the access to basic social services like water, health, education and other social services in different parts of the country. Because of the poor social services in the country, various stakeholders including; donors, private sectors, and religious institutions have played a significant role in the development of social service in the country [6]. Despite the presence of various stakeholders being in the frontline to promote improved social services in the region, there have been still some challenges which face most of the rural citizens in the country. These challenges include the prolonged long distance walking in search of health services and water services especially in the rural Tanzania areas. Until 2017, it was estimated that about $39 \%$ of Tanzanians still walk in search for water services, likewise, $35 \%$ of Tanzanians by that same year (2017) were estimated have insufficient access to clean water [15]. However, there have been varying statistics from The National Bureau of Statistics NBS (2016) about the access to clean water in the country. It states that access to clean water in Tanzania has varied between $40 \%$ and $50 \%$ over the ten years with nine out of ten surveys showing data within this range. Likewise, the Ministry of Water reported higher access of between $50 \%$ and $60 \%$ in the same period of time. Furthermore, Tanzania is also mentioned to be one of the developing countries which have very poor roads especially in the rural areas. It is reported by [15] that the roads in the rural areas in Tanzania are so bad. Because of roads problem in the country, farmers in the rural areas have been experiencing problems in transporting their goods and services from rural to urban areas. This problem of roads infrastructure in the country has caused some impacts to the economic growth of the country bearing in mind that about $80 \%$ of Tanzanians live in the rural areas and they are the main producers of both food and cash crops for the entire country. It is estimated that the quality of paved roads in the whole country in Tanzania is only about $40 \%$ of the trunk roads with less than $9 \%$ of classified network. The report issued by the Prime Minister's Office (2014) further confirms that the state of roads in Tanzania is still one of the major stumbling blocks to the development of the country. The report establishes that $23 \%$ of the classified district roads across the country are in good condition, $34 \%$ are fair while $43 \%$ are in poor condition. In nutshell, Tanzania is one 
amongst the developing countries where still suffers from poor infrastructure including roads, poor housing, insufficient access to clean water, and poor health services. Mwanza region, particularly Misungwi district where this study was done is one of the most affected areas in the country. It is estimated that out of about 3000,000 residents of Misungwi, only eight thousand have access to safe and clean water. However, limitations to water access can be grouped according to technical, social, and political factors. There are technical limitations in both developing and developed countries as noted by Ernest (2017). Furthermore, the state of roads in the country is still a challenge in most of the rural areas in Tanzania. It is confirmed [12] that roads in most of the rural areas in Tanzania have continued to be one of the challenges facing residents in those areas. Lastly, the issue of health services in Tanzania still attract for more interventions though there are currently gradual improvements in the sector. The Ministry of Health and Social Welfare report of $2013 / 2014$ shows that by 2013 there were about $72 \%$ of Tanzanians who walked about $5 \mathrm{~km}$ for health services while in June 2010 there about 51\% compared with 48\% who walked same km for health services in June 2009.

\section{3. "Maendeleo vijijini" Program}

The maendeleo vijijini is a radio program aired by radio SAUT FM. This is a community radio station owned by St Augustine University of Tanzania and it operates and serves both students and the neighbouring community around Lake Victoria region. Apart from being a teaching radio station, the radio is devoted towards serving the local community particularly in the social and economic perspectives such as the promotion of human rights, government policies and priorities, development matters and many other issues. The word "maendeleo vijijini" in a literally meaning refers to the concept of rural development. Thus, "maendeleo vijijini" programme is one of the programmes aired by radio SAUT for the purpose of serving and promoting rural development in the Lake zone region. Initially, the programme had started as "Pambana na Umaskini" [fight with poverty] program in 2015 whereby it reached diverse group of audiences including farmers, pastoralist, women, youth, family leaders' experts and government leaders. In late 2015, the "pambana na umasikini [fight poverty] program was changed into a new program called "maendeleo vijijini" [rural development]. The focus of this new program was directed towards promoting rural development in the lake zone region. Specifically, the program paid much attention on the issues of the constructions on modern houses in the rural areas, improved health services, and construction of good roads in the villages of Iteja, Koromije, Mapilinga and Ng'ombe in Misungwi District. Until 2018, the "maendeleo vijijini" program was confirmed to have been reaching about 3 million households in the rural areas of Mwanza, Mara, Kagera, Geita and Simiyu regions with its focus on the construction of good roads in the rural areas, availability and provision of health services and availability of safe and clean water. Since this is a community based program, most of the sources and participants of this program have been farmers, pastoralists, women, youths, family leaders, government leaders as well as the local leaders in the rural areas where the program covers.

Research Question

To what extent has "Maendeleo Vijijini" Program contributed to the improvement of social services in Misungwi district?

\section{Research Methodology}

This study was carried out in Misungwi district in Mwanza region, Tanzania. The data collection was done between February 2019 and June 2019. This is a qualitative research whereby in-depth interviews were used to collect data from the respondents. With qualitative research, it was expected that this approach would enable to get more insights, detailed, and in-depth information from the respondents [9, 11]. The target population for the study were the government officials from Misungwi district and local leaders in the rural Misungwi area. Purposive sampling technique was used to select the respondents. The composition of the respondents included three (3) head of units from Misungwi District Council, (ii) 20 members of the village development committee of (a) Planning and Finance, (b) Social Welfare and Education, and (c) Planning and Finance committee, and (iii) 10 local leaders. Thus, a total of 33 respondents were interviewed in this study. Thematic analysis was used to analyse the data whereby all necessary process, including transcription verbatim, initial coding, coding, theming, and all other cleaning $[2,13,16]$ process before embarking on the established themes which were used in the analysis and discussion segment.

\section{Findings and Discussions}

Research question

To what extent has the Maendeleo Vijijini Program contributed to the improvement of social services in Misungwi District?

The focus of the study was directed towards an evaluation of the maendeleo vijijini program and how it has played role towards the improvements of social services particularly roads, safe drinking water, and health services in the rural areas of Misungwi district. The findings show that "maendeleo vijijini" program plays a significant contribution towards the improvement of roads in the rural Misungwi areas. Majority $(60.6 \%)$ of the respondents from the community development committee confirmed that the program has been an instrumental towards awakening and sensitizing residents in the rural Misungwi area to understand the importance of roads in relation to their economic developments in the rural areas. They reported that the maendeleo vijijini program has been creating awareness and encouraging citizens to fully participate in improving and maintaining the quality of their roads in the rural areas. The 
findings further reveal that $30.3 \%$ of respondents (local leaders) who were interviewed said the program has improved the road services through involving the locals into road construction and maintenance especially in rural areas. However, the findings show that the government official particularly the head of unit responsible with roads, water, and health in Misungwi district had varying opinions towards the contribution of the program in the improvement of road services in the district. According to him, because of poor coverage of the program, there have been very little contributions of the program towards the improvements of road services in the Misungwi rural areas. Furthermore, the findings indicate that there is a very little contribution of the program towards the improvement of safe drinking water in the rural Misungwi district. The findings show that majorities $(55.4 \%)$ of the respondents were not certified with the coverage and contribution of the program in the water related issues. They reported that because of poor coverage and very little contents on water related issues, the program has not been so useful in promoting and covering the issue of safe drinking water. However, there were very minimal responses (30\%) from respondents who acknowledged the contents of the program claiming that it had played some significant contribution towards the improvement of safe drinking water. The asserted and confirmed that the program the program has been educating and encouraging the people the importance of harvesting water from rainfalls during wet seasons. Likewise, on the area of health services, the findings show that the program had played significant contributions. It was revealed that the majority $(72.1 \%)$ of the respondents confirmed that the program had helped people in the rural areas of Misungwi towards the improvement of health services in their areas. It was stated by majority of respondents that the program had managed to mobilize people in the rural Misungwi areas to build more health centers close to their home places. Likewise, the program had managed to prepare some documentaries covering the poor health services and how people in the rural areas were walking long distance for health services. These documentaries helped in awakening government officials to improve the provision of health services in those areas.

\section{Discussions}

Overall, the practical implications of these findings are that community radios are still very vibrant and play noticeable contributions in local communities they serve. With reference to maendeleo vijijini program, it is beyond reasonable doughty that this program has been an instrumental towards mobilizing and educating people in the rural areas to fully participate in the improvements of their own social services instead of waiting from the governments intervention. Similarly, these findings imply that the state and level of social services in most of the rural areas in Tanzania is still a challenge. Though it was not part of the data collection method of this study, it was observed that the state of roads in the study area were so poor to the extent that farmers in some parts of the area could not manage to transport their goods from the rural areas to the urban areas. In other words, this contributes to the low level of development in the country since the transit of goods and services from the production areas in the rural areas to the market places in the urban areas is not guaranteed. Furthermore, what surprises more from these findings is that the government of Tanzania appears to pay very little attention in improving the state of roads in the rural areas of the country. This is so astonishing because most of the constructions and rehabilitations of roads in the country is directed towards the roads in the urban areas than in the rural areas. Perhaps it would have been prudence for the government to construct the roads both in the rural areas where most of the goods are produced and transported to the urban areas where they are sold and used by the urban population who are expected to be about $20 \%$ of the entire population in the country. On the other hand, through these findings, it has been learnt that community radio stations in Tanzania and perhaps in the rest of other developing countries still face a number of challenges which make them not work effectively. One of the major challenges is the coverage problem where the level of coverage of these radio stations is very poor especially in the rural areas. This problem of coverage has caused many listeners and audiences in the rural areas lose concentration and interests with the community radios instead, they often listen to other entertaining radio stations. In other words, most of the constructive programs like maendeleo vijijini program fail to bear fruits because of the poor coverage and low level of listenership among audiences in the rural areas. Likewise, these findings have informed us that when the level of coverage of community radios is perfect, there has always been a positive participation of audiences and local leaders in some of the programs. It was observed that there are some audiences in the rural areas where the coverage of the program was perfect they fully participated in propagating the contents of the maendeleo vijijini program. This is a good indicator for the government and other stakeholders to further realize the potentiality of community radios and their contributions to the economic development of the country since majority of the community radio stations are established to serve the local community where most of the production activities are carried out there. In summary, these findings inform us that community radio stations are still very important in the developing countries as previous scholars have confirmed. Their programs and contents if they are well prepared and structured, they can cause great impacts in those communities they serve. It should also be noted that for the community radios to fully play their intended roles in the communities, their programs and contents has to be improved so as to suits the needs of the communities they serve.

\section{Conclusions}

The findings from this study have managed to enlighten 
other scholars and stakeholders in Tanzania and perhaps across all developing countries about the importance of community radio stations in fostering the development of social services. Likewise, these findings have continued to confirm some of the challenging factors facing most of the community radios in Africa as earlier stated by White (2013). Furthermore, another important aspect of these findings is that the findings have managed to inform both government official and other stakeholders the importance of using programs prepared by community radio stations in educating and motivating audiences the importance of their participation in all social and economic activities in their communities. Lastly, it is the expectations of the researcher that the findings from this study will be taken positively by all developmental stakeholders and where necessary some steps should be taken into consideration in making sure that community radio stations continue to be used for the developmental activities.

\section{References}

[1] Aleena, B (2014) Community radio for development a case study of Radio Lumbini in Nepal.

[2] Burke, J. (2014). Education Research: Qualntitative, Qualitative, and Mixed Approaches. New York: Sage Publishers.

[3] Cameron, J., Hunter, P., Jagal, P., \& \& Pond, K. (2011). Valuing Water, Valuing Livelihood. London: IWA Publishers.

[4] Chaudhuri, S. \&. (2017). Potable Water Sources in India. General Articles, 113 (17), 3-17

[5] Dagdeviren, H. (2011). Access to Water in the Slams of SubSaharan Africa. Development Policy Review, 24 (4).

[6] Darul, K. \&. Balozi, M. (2014). Constructing Theory With Big result Now: Contribution of Tanzania to the Theory of Knowledge Sharing Behaviour. International Journal for Innovation Education and Research, 2-08, 7-21.

[7] EWURA. (2017). Water Utilities Performance Review Report for 2016. Dar es Salaam: EWURA.

[8] Harmonious, M. (2017). Definitions for Social Sciences.

[9] Jackson, R. \&. (2016). What is Qualitative Reearch. Dar Es Salamm.
[10] Kunzeler, D. \&. (2017). Varieties and Drivers of Social Welfare inSub-Saharan Africa: A Critical Analysis. Johanesburg: JUta.

[11] Khuan, L. \&. (2015). Why Use Qualitative Research Methods to Understand the Meaning of Clients in Health Care.

[12] Koutronas, E. (2017). Understanding Social Welfare: Basic Concepts and Definitions.

[13] Lammers, W. \&. (2013). Fundamental of Behavioral Research.

[14] Lawrence, J. (2010). Health Programming and Community Based Radio Stations in Sub-Saharan Africa: An Example from Zambia: A MSC Thesis submitted to the university of Pittsburgh. University of Pittsburdh.

[15] Makangale, D. (n.d.). Tanzania Social Services Devlivery Progressing., (p. 2016). dar Es Salaam.

[16] Marvasti, A. (2014). Analysing Observations. Sage Publishers.

[17] Mwidima P. (2019). The Integration of Community Radios in Achieving the Goals of the Big Results Now in Tanzania. International Journal of Science and Research, 8 (7), 18241848 .

[18] Ornellas, A. \&. (2016). The Global Social Definition: Ontology, Implications and Challenges. Journal of Social Work, 27-39.

[19] Prodhan, M. \&. (2012). The Importance of Social Welfare in Developing World. Journal of International Social Issues, 1, 21-37.

[20] Sarr, A. (2014). Community radio Tolls to Promote Peace, Culture, Democracy and Development in Africa. AMARC Afrique.

[21] Seidu, A. (2011, September). The Role of Community Radio in Livelihood Improvement: The Case of Simli Radio. Journal of Field Action, 12, 17-34.

[22] Sourou (2013). The Centrality of Community Communication in the Structure of African Communication. African Communication Research, 135-140.

[23] Tahir, S. (2016). Community radio a Tool of Social Change: Still a Far Cry in Parkistan. Karachi.

[24] White, R. (2013). The Centrality of Community Communication in the Structure of African Communication. African Communication Research, 135-140. 